\title{
HUBUNGAN ANTARA POLA ASUH ORANG TUA DAN KETAATAN BERIBADAH DENGAN PERILAKU SOPAN SANTUN PESERTA DIDIK
}

\author{
Putri Risthantri, Ajat Sudrajat \\ PPS Universitas Negeri Yogyakarta, Universitas Negeri Yogyakarta \\ yudiaputri8@gmail.com, ajat@uny.co.id
}

\begin{abstract}
Abstrak
Penelitian ini bertujuan untuk: (1) mengetahui hubungan antara pola asuh orang tua dengan perilaku sopan santun peserta didik; (2) mengetahui hubungan antara ketaatan beribadah dengan perilaku sopan santun peserta didik; ( 3) mengetahui hubungan antara pola asuh orang tua dan ketaatan beribadah secara bersama-sama dengan perilaku sopan santun peserta didik di SMP Negeri se Kecamatan Ngaglik Kabupaten Sleman. Penelitian ini merupakan jenis penelitian kuantitatif dengan desain korelasional. Penelitian dilaksanakan di SMP Negeri 1, SMP Negeri 2, SMP Negeri 3, dan SMP Negeri 4 Kecamatan Ngaglik Kabupaten Sleman. Penelitian dilaksanakan pada bulan Oktober 2014 sampai Juni 2015. Populasi sebanyak 1.767 siswa. Sampel diambil secara simple random sampling. Data dikumpulkan melalui angket. Uji validitas menggunakan validitas konstrak dengan model Confirmatory Factor Analysis (CFA). Analisis data meliputi analisis deskriptif, pengujian persyaratan analisis, dan pengujian hipotesis. Hasil penelitian menunjukkan bahwa: (1) ada hubungan yang positif dan signifikan antara pola asuh orang tua dengan perilaku sopan santun peserta didik; (2) ada hubungan yang positif dan signifikan antara ketaatan beribadah dengan perilaku sopan santun peserta didik; (3) ada hubungan yang positif dan signifikan antara pola asuh orang tua dan ketaatan beribadah secara bersama-sama dengan perilaku sopan santun peserta didik.
\end{abstract}

Kata kunci: Pola asuh orang tua, ketaatan beribadah, sopan santun

\section{RELATIONSHIP BETWEEN PARENTING PARENTS AND WORSHIP OBEDIENCE WITH GOOD MANNERS FOR JUNIOR HIGH SCHOOL STUDENTS}

\author{
Putri Risthantri, Ajat Sudrajat \\ ${ }^{1}$ PPS Universitas Negeri Yogyakarta, Universitas Negeri Yogyakarta \\ yudiaputri8@gmail.com, ajat@uny.co.id
}

\begin{abstract}
This study aims to find out: (1) the relationship between parenting parents with good manners of the learners; (2) the relationship between the worship obedience with good manners of the learners; (3) the relationship between parenting parents and worship obedience together with good manners of the learners at SMPsin Sub district Ngaglik, Sleman. This study uses a quantitative research with correlational design. The research was conducted at SMP Negeri 1, Junior High School 2, SMP Negeri 3, and SMP Negeri 4 in Sub district Ngaglik, Sleman. The research was conducted from October 2014 to June 2015. The total population are 1767. The total sample were taken by simple random sampling. Data were collected through questionnaires. The test of validity using the construct validity Confirmatory Factor Analysis (CFA). Data analysis performed included descriptive analysis, testing requirements analysis, and hypothesis testing. The results show that: 1) there is a positive and significant relationship between parenting parents with good manners of the learners; 2) there is a significant and positive relationship worship obedience with good manners of the learners; 3) there is a positive and significant relationship between parenting parents and acts of worship obedience together with good manners.
\end{abstract}

Keywords:Parenting parents, worship obedience, good manners 


\section{Pendahuluan}

Sikap tidak menghormati dan tidak menghargai orang lain, bahkan sampai melakukan tidakan bullying termasuk penyerangan terhadap kelompok remaja lain memperlihatkan remaja telah jauh dari kebiasaan berlaku sopan santun. Dari tiga kota pelaksanaan survei mengenai gambaran bullying di sekolah, Yogyakarta mencatat angka tertinggi dibanding Jakarta dan Surabaya. Ditemukan kasus bullying di 70, 65 persen SMP dan SMU di Yogyakarta.

Psikolog Universitas Indonesia (UI) Ratna Juwita, yang melakukan penelitian ini, mengatakan, tingginya kasus bullying di Yogyakarta belum diketahui sebabnya (http:// nasional.kompas.com, diakses tanggal 12 Juni 2015). Kondisi tersebut tentu kontraproduktif dengan upaya membangun moral bangsa. Dalam hal ini perlu adanya revitalisasi nilai-nilai moral untuk membangun karakter bangsa.

Sebagai bentuk optimisme, pemerintah Indonesia telah menetapkan pembangunan karakter sebagai salah satu target yang harus direalisasikan ditengah program pembangunan lainnya, contohnya dengan memberikan pendidikan karakter (La Raman dan Zamroni, 2014, p.14). Namun hal ini perlu adanya kerjasama antara pemerintah, orang tua dan sekolah agar nilai-nilai moral mewujud dalam sikap dan perilaku anak, salah satunya ditunjukkan dengan perilaku sopan santun.

Sopan santun merupakan perwujudan budi pekerti luhur yang diperoleh melalui pengalaman, pendidikan, dan teladan dari orang tua, guru, para pemuka agama, serta tokohtokoh masyarakat. Sopan santun merupakan tata krama dalam kehidupan sehari-hari sebagai cerminan kepribadian dan budi pekerti luhur yang di dalam Islam lebih dikenal dengan konsep akhlak (Marzuki, 2009, p.8).

Sopan santun juga merupakan cerminan akhlak yang dapat dicapai melalui proses pembelajaran anak di sekolah. Transfer pengetahuan yang diukur dengan nilai belum mampu membentuk pribadi yang berakhlak mulia. Sopan santun justru bergantung pada bagaimana proses pembinaan akhlak anak. Akhlak selalu melekat dan tampak dalam bentuk perbuatan (Mu'niah, 2011, p.104).

Bentuk tingkah laku sosial anak, seperti sikapnya terhadap orang lain dan kelompok orang sebagian besar berasal dari apa yang dipelajari. Sikap ini diperoleh dari penyesuaian sosial, khususnya tata cara kehidupan keluarganya. Sikap dasar sosial yang didapat ini kelak masih dapat berubah, disebabkan oleh pengalaman yang terjadi (Notosoedirdjo \& Latipun, 2011, p.208). Sopan santun yang dimiliki anak-anak sebagian besar terbentuk melalui pendidikan keluarga. Sejak dari bangun tidur hingga akan tidur kembali, anak-anak menerima pengaruh dan pendidikan dari lingkungan keluarga. Pola kepemimpinan orang tua dalam keluarga akan mempengaruhi perilaku dan sopan santun anak.

Pembentukan sopan santun dimulai dari keluarga. Anak akan meniru perilaku orang tua dalam kehidupan sehar-hari. Anak yang mempunyai perilaku sopan pada umumnya berasal dari keluarga yang juga sopan, demikian pula sebaliknya anak yang mempunyai perilaku kasar tentunya perilaku keluarga juga kasar. Upaya menanamkan sopan santun di dalam keluarga yaitu dengan cara orang tua memberikan contoh-contoh penerapan perilaku sopan santun di depan anak. Demikian pula di sekolah, guru harus memberikan contoh perilaku sopan santun. Masalahnya, guru pada umumnya lebih fokus pada pencapaian prestasi akademik semata (Ujiningsih dan Antoro, 2010, p.2).

Berdasarkan hasil wawancara pada bulan Oktober sampai dengan November 2014, di seluruh SMP Negeri Kecamatan Ngaglik secara umum masih sering dijumpai sejumlah masalah terkait dengan perilaku sopan santun. Perilaku peserta didik yang sering dikeluhkan oleh guru seperti tidak menyapa atau permisi ketika berjalan didepan guru, memanggil orang yang lebih tua dengan namanya langsung, berbicara kasar dengan orang lain, sering mengumpat dan sebagainya.

Aktivitas remaja SMP di Kecamatan Ngaglik telah mengalami perubahan seiring dengan kemajuan teknologi informasi. Remaja-remaja lebih tertarik pada dunia maya daripada aktivitas di dunia nyata. Remajaremaja yang aktif dalam kegiatan bersama pun tidak selalu positif, misalnya dengan bergabung dalam geng-geng remaja. Fenomena munculnya geng remaja di Ngaglik merupakan sinyal yang kurang baik dalam kehidupan sosial remaja. Aktivitas di dunia maya terutama di media sosial telah menjadikan anak kurang terlatih untuk bertingkah laku sopan santun dengan orang lain. 
Aktivitas geng juga sering memperlihatkan perilaku yang kurang terpuji seperti ugal-ugalan di jalan, vandalisme, dan tawuran. Remaja di Ngaglik semakin sedikit yang tertarik pada kegiatan keagamaan, baik di sekolah ataupun di masyarakat. Berdasarkan uraian diatas menarik untuk diteliti hubungan antara pola asuh orang tua, dan ketaatan beribadah terhadap perilaku sopan santun.

Ibadah bermakna melakukan ketaatan dalam mencapai keridhaan Allah (Rajab, 2011, p.74). Ketaatan ibadah dapat dilihat dari ketaatan menjalankan ibadah mahdlah (hubungan dengan Tuhan) dan ketaatan dalam menjalankan ibadah ghairu mahdlah yaitu ibadah horizontal (sosial) yang berhubungan dengan makhluk atau lingkungan (Zuriah, 2008, p.28). Dapat disimpulkan bahwa ketaatan beribadah sebagai kepatuhan dan kesetiaan seorang hamba kepada Tuhan dalam menjalankan perintah dan menjauhi larangan-Nya. Ibadah dilakukan dengan cara mengabdikan dirinya dengan penuh ketakwaan dan mengharap ridha dari-Nya dan juga melaksanakan ibadah dengan penuh keikhlasan dan kesopanan dalam menghadap-Nya.

Peran keluarga, terutama orang tua sangat penting dalam membentuk perilaku anak. Menurut Nurharyati dkk (2013, p.5051), menyatakan bahwa pola asuh merupakan pola interaksi antara orang tua dan anak yaitu bagaimana cara sikap atau perilaku orang tua saat berinteraksi dengan anak, termasuk cara penerapan aturan, mengajarkan nilai/norma, memberikan perhatian dan kasih sayang serta menunjukkan sikap dan perilaku baik sehingga dijadikan panutan bagi anaknya.

Notosoedirdjo \& Latipun (2011, p.207) menyatakan bahwa tata cara kehidupan keluarga akan membentuk sikap serta perkembangan kepribadian anak. Ketiga jenis tata cara kehidupan keluarga, yaitu:

Demokratis, anak dibesarkan dalam susunan keluarga yang demokratis, membuat anak mudah bergaul, aktif, dan ramah sehingga anak belajar menerima pandangan orang lain;

Permisif, anak yang dibesarkan dalam keluarga permisif akan membuat anak tidak aktif dalam kehidupan sosial dan dapat dikatakan anak menarik diri dari kehidupan sosial dan mempunyai kecenderungan untuk mudah membenci seseorang;
Otoriter, anak yang dibesarkan dalam keluarga yang otoriter biasanya akan bersifat tenang, tidak melawan, tidak agresif dan mempunyai tingkah laku yang baik. Anak akan berusaha menyesuaikan pendiriannya dengan kehendak orang lain (yang berkuasa, orang tua)

Aspek pola asuh orang tua yang sangat penting pada anak adalah penerimaan dan kontrol. Penerimaan adalah dukungan dan kasih sayang yang terlihat dari senyuman, pujian, dan dorongan. Kontrol mengacu pada pengawasan terhadap aktivitas anak (Shaffer and Kipp, 2014, p.541). Pola asuh ini tampak dari pelaksanaan peranan keluarga. Dalam hal ini, terdapat empat prinsip peranan keluarga, yaitu modeling, mentoring, organizing, dan teaching sebagai berikut (Yusuf, 2008, p.47).

Modelling (example of trustworthness). Orangtua adalah contoh atau model bagi anak. Orangtua merupakan model yang pertama dan terdepan bagi anak (baik positif atau negatif) dan merupakan pola bagi "way of life" anak. Cara berpikir dan berbuat anak dibentuk oleh cara berpikir dan berbuat orang tuanya. Melalui "modelling" ini juga anak akan belajar tentang (1) sikap proaktif, (2) sikap respek dan kasih sayang. Sikap proaktif ini dilakukan dengan memberikan contoh dan teladan tentang perbuatan baik yang perlu dipertahankan dan perbuatan tidak baik yang harus ditinggalkan. Sikap respek dan kasih sayang ini tampak dari adanya hubungan yang harmonis antar anggota keluarga.

Mentoring, yaitu kemampuan untuk menjalin atau membangun hubungan, investasi emosional (kasih sayang kepada orang lain) atau pemberian perlindungan kepada orang lain secara mendalam, jujur, pribadi dan tidak bersyarat. Kedalaman dan kejujuran atau keikhlasan memberikan perlindungan ini akan mendorong orang lain untuk bersikap terbuka dan mau menerima pengajaran, karena dalam diri mereka telah tertanam perasaan percaya. Dalam hal ini, dibutuhkan komunikasi dua arah antara anak dan orang tua. Orang tua merupakan mentor pertama bagi anak yang menjalin hubungan dan memberikan kasih sayang. Untuk itu, orang tua harus memperhatikan keinginan dan pendapat anak diperhatikan. Sebagai mentor, orang tua harus memberikan bimbingan dengan penuh pengertian. Ada lima cara yang dapat dilakukan yaitu (1) mendengarkan hati orang lain dengan hati 
sendiri, (2) berbagi wawasan, emosi dan keyakinan, (3) memberikan ketegasan kepada orang lain dengan kepercayaan penilaian, konfirmasi, afirmasi dan dorongan. Dalam hal ini orang tua berperan menentukan peraturanperaturan dan disiplin dengan mempertimbangkan keadaan, perasaan dan pendapat anak. (4) mendoakan orang lain dengan ikhlas dan jiwa yang paling dalam, (5) berkorban untuk diri orang lain.

Organizing yaitu keluarga seperti perusahaan yang memerlukan kerjasama antar anggota keluarga dalam menyelesaikan tugastugas atau memenuhi kebutuhan keluarga. Orang tua melakukan sesuatu dalam keluarga dengan cara musyawarah. Dalam hal ini keluarga bertugas menyelesaikan hal-hal yang penting (Yusuf, 2008, p.48). Penyelesaian masalah dengan musyawarah dapat dicapai ketika di dalam keluarga ada hubungan saling menghormati satu sama lain. Hubungan yang harmonis antar anggota keluarga menjadi modal utama terwujudnya musyawarah.

Teaching. Orang tua berperan sebagai guru bagi anak-anaknya tentang dasar-dasar kehidupan. Orang tua berupaya memberdayakan prinsip-prinsip kehidupan, sehingga anak memahami dan melaksanakannya. Ketika orang tua menyampaikan larangan dan perintah maka harus disampaikan dengan menggunakan kata-kata yang mendidik. Dalam hal ini, orang tua mengajak anak untuk mengalami tentang apa yang anak kerjakan dan alasan mengapa suatu tindakan atau pekerjaan dilakukan. Orang tua melatih anak agar mampu menyikapi masalah dengan tenang, wajar dan terbuka terhadap masukan atau pendapat dari orang lain.

Pendidikan di dalam keluarga menjadi bekal bagi anak dalam membangun hubungan sosial yang lebih luas di luar rumah termasuk di sekolah. Akhlak atau perilaku sopan santun yang dipelajari di rumah akan tercermin dalam perilaku siswa di sekolah. Hasil wawancara di SMP Negeri 1, SMP Negeri 2, SMP Negeri 3, dan di SMP Negeri 4 mengungkapkan bahwa pada jam-jam istirahat dan jam pulang sekolah banyak siswa yang berkeliaran di luar sekolah untuk sekedar duduk-duduk di warung tidak jauh dari sekolah. Sebagian besar dari mereka tampak menikmati merokok. Mereka duduk dan berbicara dengan bahasa ngoko (bahasa jawa kasar) kepada penjual, bahkan muncul kata- kata yang kasar ketika berbicara dengan siswa lain.

Sejumlah permasalahan yang ditemukan di SMP Negeri di Kecamatan Ngaglik Sleman yaitu: (1) terkikisnya nilai-nilai sebagai identitas suatu komunitas akibat globalisasi, (2) kurangnya waktu komunikasi antara orang tua dan anak, (3) kurangnya pemahaman dan penghayatan terhadap pelaksanaan agama yang dianutnya, (4) menurunnya perilaku sopan santun baik kepada orang tua, guru maupun kepada teman, (5) peserta didik-siwa SMP di Kecamatan Ngaglik masih banyak yang berperilaku kurang sopan dan kurang tertarik pada kegiatan ibadah keagamaan.

Penelitian ini bertujuan untuk mengetahui: (1) hubungan antara pola asuh orang tua dengan perilaku sopan santun peserta didik di seluruh SMP Negeri Kecamatan Ngaglik Kabupaten Sleman, (2) hubungan antara ketaatan beribadah dengan perilaku sopan santun peserta didik di seluruh SMP Negeri Kecamatan Ngaglik Kabupaten Sleman, dan (3) hubungan antara pola asuh orang tua dan ketaatan beribadah secara bersama-sama dengan perilaku sopan santun peserta didik di seluruh SMP Negeri Kecamatan Ngaglik Sleman.

\section{Metode Penelitian}

Penelitian ini menurut metode yang digunakan termasuk dalam penelitian survei. Pendekatan yang digunakan dalam penelitian ini adalah pendekatan kuantitatif. Penelitian ini menekankan pada pengukuran variabel dengan angka dan melakukan analisis data dengan prosedur statistik dengan menggunakan analisis korelasi produck moment dan regresi linier berganda.

Penelitian dilaksanakan di SMP Negeri se Kecamatan Ngaglik Kabupaten Sleman, DI Yogyakarta. Lokasi ini dipilih karena di SMP-SMP di Kecamatan Ngaglik pada bulan Agustus 2014 sampai bulan Juni 2015. Populasi dalam penelitian ini adalah peserta didik di SMP Negeri se Kecamatan Ngaglik Kabupaten Sleman sebanyak 1767, dengan menggunakan Tabel Krejcie didapatkan sampel sebanyak 313

Variabel bebas dalam penelitian ini adalah pola asuh orang tua dan ketaatan beribadah. Variabel terikat yang digunakan dalam penelitian ini adalah perilaku sopan santun. Pola asuh orang tua merupakan pola interaksi 
antara orang tua dan anak yaitu bagaimana cara sikap atau perilaku orang tua saat berinteraksi dengan anak, termasuk cara penerapan aturan, mengajarkan nilai/norma, memberikan perhatian dan kasih sayang serta menunjukkan sikap dan perilaku baik sehingga dijadikan panutan bagi anaknya. Pola asuh orang tua dalam penelitian ini dilihat dari aspek modelling (example of trustworthness), mentoring, organizing, dan teaching.

Taat adalah patuh, setia, ataupun tunduk. Tingkat ketaatan adalah tinggi rendahnya suatu kepatuhan, kesetiaan, kesalehan. Menurut syara' ibadah adalah semua bentuk pekerjaan yang bertujuan memperoleh keridhaan Allah Swt dan mendambakan pahala dari-Nya di akhirat.

Ketaatan beribadah yang dimaksud dalam studi ini adalah penyerahan dengan hati, perkataan dan perbuatan untuk mengerjakan perintah-Nya dan meninggalkan larangan-Nya, yang dilakukan secara ikhlas untuk mencapai keridhaan Allah Swt, dan mengharap pahala-Nya serta dilakukan secara terus-menerus dalam kehidupan manusia. Ketaatan beribadah dalam penelitian ini dilihat pada aspek ibadah shalat, puasa, membaca Alqur'an dan ibadah yang dilakukan terhadap sesama manusia (ibadah sosial).

Variabel terikat yang digunakan dalam penelitian ini adalah perilaku sopan santun. Perilaku sopan santun adalah perilaku seseorang yang berhubungan dengan cara atau tindakannya yang dianggap layak dan baik di mata masyarakat sekitar sehingga dapat dihargai seperti cara berpakaian, berperilaku, bersikap, bertutur kata, dan lain-lain. Perilaku sopan santun dalam penelitian ini berkaitan dengan perilaku terhadap diri sendiri dan perilaku terhadap orang lain.

Instrumen yang dipergunakan dalam penelitian ini adalah kuesioner pola asuh orang tua, kuesioner ketaatan beribadah, dan kuesioner perilaku sopan santun. Penyusunan instrumen merupakan sebuah kegiatan dalam penelitian yang harus dilakukan secara cermat

Titik tolak penyusunan instrumen adalah definisi operasional variabel-variabel penelitian yang telah ditetapkan untuk diteliti. Berdasarkan definisi operasional tersebut, ditentukan indikator yang akan diukur. Indikator ini kemudian dijabarkan menjadi butir-butir pertanyaan atau pernyataan. Supaya penyusunan instrumen lebih sistematis, mudah dikontrol, dikoreksi dan dikonsultasikan kepada ahli, komponen-komponen dari variabel yang akan diteliti dijabarkan menjadi itemitem instrumen. Item-item instrumen harus disusun dengan bahasa yang jelas sehingga semua pihak yang berkepentingan tahu apa yang dimaksud dalam item instrumen tersebut. Agar penyusunan instrumen dapat dilakukan dengan baik, berikut ditampilkan kisikisi instrumen penelitian.

Validitas instrumen diuji dengan menggunakan Confirmatory Factor Analysis (CFA). Azwar (2012, p.123) menyatakan bahwa CFA digunakan untuk memverifikasi banyaknya dimensi yang mendasari bangunan suatu tes (faktor) dan pola hubungan antara item dengan faktor (factor loading).

Hasil Analisis Faktor Variabel Pola Asuh Orang Tua menunjukkan uji berdasarkan nilai KMO > 0,5 dan pengujian Bartlett of Sphericity yang signifikan $(\mathrm{p}<0,05)$, maka analisis faktor layak dilakukan. Nilai MSA yang terlihat pada anti image matriks didapatkan semua lebih dari 0,5 dengan nilai terendah sebesar 0,533. Berdasarkan hal tersebut, maka tidak ada item yang direduksi. Semua item dapat diprediksi oleh item lain dan bisa dianalisis lebih lanjut.

Hasil analisis faktor untuk variabel ketaatan beribadah, didapatkan nilai KMO sebesar 0,695, nilai Bartlett of Sphericity sebesar 428,952 dan p sebesar 0,000. Berdasarkan nilai KMO > 0,5 dan pengujian Bartlett of Sphericity yang signifikan $(\mathrm{p}<0,05)$, maka analisis faktor layak dilakukan. Nilai MSA yang terlihat pada anti image matriks didapatkan semua lebih dari 0,5 dengan nilai terendah sebesar 0,513. Berdasarkan hal tersebut, maka tidak ada item yang direduksi. Semua item dapat diprediksi oleh item lain dan bisa dianalisis lebih lanjut.

Hasil analisis faktor untuk variabel perilaku sopan santun, didapatkan nilai KMO sebesar 0,712, nilai Bartlett of Sphericity sebesar 614,932 dan p sebesar 0,000. Berdasarkan nilai KMO $>0,5$ dan pengujian Bartlett of Sphericity yang signifikan $(\mathrm{p}<0,05)$, maka analisis faktor layak dilakukan. Nilai MSA yang terlihat pada anti image matriks didapatkan semua lebih dari 0,5 dengan nilai terendah sebesar 0,552. Berdasarkan hal tersebut, maka tidak ada item yang direduksi. Semua item dapat diprediksi oleh item lain dan bisa dianalisis lebih lanjut. 
Pengujian reliabilitas dalam penelitian ini digunakan formula koefisien Alpha. Koefisien Alpha umumnya harus, minimal, lebih besar dari atau sama dengan 0,70 untuk tujuan penelitian (Johnson \& Christensen, 2012:142). Hasil pengujian reliabilitas untuk instrumen pola asuh orang tua $\left(\mathrm{X}_{1}\right)$, ketaatan beribadah $\left(\mathrm{X}_{2}\right)$, dan perilaku sopan santun $(\mathrm{Y})$ mempunyai nilai cronbach alpha lebih besar dari 0,7 sehingga dapat disimpulkan bahwa semua instrumen yang dipergunakan reliabel.

Data yang terkumpul kemudian diolah dan dianalisis dengan teknik deskriptif dan uji persyaratan analisis serta uji hipotesis. Uji persyaratan analisis dilakukan agar hasil analisis memenuhi persyaratan analisis.Uji persyaratan analisis dalam penelitian ini meliputi uji normalitas, uji linieritas, dan uji multikolinieritas.

Uji normalitas data dilakukan dengan menggunakan Kolmogorov-Smirnov Test dan dilakukan dengan menggunakan software SPSS. Apabila nilai Kolmogorov-Smirnov-Z lebih besar dari nilai kritis atau nilai $p<0,05$, maka dapat diduga bahwa distribusi data adalah tidak normal. Pengujian dilakukan dengan teknik regresi menggunakan software SPSS, dan dilihat pada uji deviation from linearity. Apabila didapatkan nilai $\mathrm{p}>0,05$ maka persamaan regresi menunjukkan linier.

Pengujian multikolinieritas dalam penelitian ini dilakukan menggunakan bantuan software SPSS dengan melihat nilai VIF (Variance Inflation Factor). Jika nilai VIF membesar maka diduga ada multikolinieritas. Sebagai aturan main (rule of thumb) jika nilai VIF melebihi angka 10 maka dikatakan ada multikolinieritas (Widarjono, 2007:118). Nilai Variance Inflation Factor (VIF) diperoleh dari rumus VIF $=1 /$ Tolerance, dan nilai Tolerance diperoleh dari rumus Tol $=1-\mathrm{R}^{2}$ (Rosadi, 2012, p.83).

Uji hipotesis dalam penelitian ini digunakan korelasi product moment dan regresi ganda dengan dua predictor. Analisis korelasi product moment digunakan untuk menguji hubungan variabel bebas secara individual terhadap variabel terikat, atau digunakan untuk menguji hipotesis pertama dan kedua. Pengujian dilakukan dengan menggunakan SPSS. Kriteria pengujian dalam penelitian ini adalah sebagai berikut : $\mathrm{H}_{0}$ ditolak jika $\mathrm{p} \leq 0,05 . \mathrm{H}_{0}$ diterima jika $\mathrm{p}>0,05$.

\section{Hasil Penelitian dan Pembahasan}

Analisis Deskriptif

Skor pola asuh orang tua diperoleh dari penyebaran kuesioner dengan item sebanyak 20 item dengan skor $1-5$, sehingga nilai tertinggi ideal sebesar $20 \times 5=100$. Berdasarkan rentang skor tersebut, maka Standar Deviasi Ideal sebesar (80) $: 6=13,33$ dan Mean Ideal $=(80: 2)+20=60$.

Tabel 1. Distribusi Frekuensi Variabel Pola asuh orang tua

\begin{tabular}{|c|c|c|c|c|}
\hline No. & Kriteria & Skor & $\mathrm{f}$ & $\%$ \\
\hline 1. & Sangat Baik & $>80$ & 6 & 1,92 \\
\hline 2. & Baik & $67-80$ & 66 & 21,09 \\
\hline 3. & Cukup & $54-66$ & 125 & 39,94 \\
\hline 4. & Tidak Baik & $41-53$ & 92 & 29,39 \\
\hline 5. & Sangat Tidak Baik & $\leq 40$ & 24 & 7,67 \\
\hline \multicolumn{3}{|c|}{ Total } & 313 & 100,00 \\
\hline
\end{tabular}

Sebagian besar responden mempunyai skor pola asuh orang tua kategori cukup, yaitu 125 responden $(39,94 \%)$. Hal ini didukung dengan nilai rata-rata sebesar 57,53 menunjukkan bahwa pola asuh orang tua peserta didik di SMP Negeri Sekecamatan Ngaglik Sleman Yogyakarta termasuk dalam kategori cukup.

Skor ketaatan beribadah diperoleh dari penyebaran kuesioner dengan item sebanyak 20 item dengan skor $1-5$, sehingga nilai tertinggi ideal sebesar 20 x $5=100$. Berdasarkan rentang skor tersebut, maka Standar Deviasi Ideal sebesar (80) : $6=13,33$ dan Mean Ideal $=(80: 2)+20=60$.

Tabel 2. Distribusi Frekuensi Variabel Ketaatan Beribadah

\begin{tabular}{llccc}
\hline No. & Kriteria & Skor & $\mathrm{f}$ & $\%$ \\
\hline 1. & Sangat Baik & $>80$ & 4 & 1,28 \\
2. & Baik & $67-80$ & 35 & 11,18 \\
3. & Cukup & $54-66$ & 129 & 41,21 \\
4. & Tidak Baik & $41-53$ & 112 & 35,78 \\
5. & Sangat Tidak Baik & $\leq 40$ & 33 & 10,54 \\
\hline \multicolumn{2}{r}{ Total } & & 313 & 100,00 \\
\hline
\end{tabular}

Sebagian besar responden mempunyai skor ketaatan beribadah kategori cukup, yaitu 129 responden $(41,21 \%)$. Hal ini di- 
dukung dengan nilai rata-rata sebesar 54,44 menunjukkan bahwa ketaatan beribadah peserta didik di SMP Negeri Sekecamatan Ngaglik Sleman Yogyakarta termasuk dalam kategori cukup.

Skor perilaku sopan santun diperoleh dari penyebaran kuesioner dengan item sebanyak 20 item dengan skor $1-5$, sehingga nilai tertinggi ideal sebesar $20 \times 5=100$. Berdasarkan rentang skor tersebut, maka Standar Deviasi Ideal sebesar (80) : $6=13,33$ dan Mean Ideal $=(80: 2)+20=60$.

Tabel 3. Distribusi Frekuensi Variabel Perilaku Sopan Santun

\begin{tabular}{llccc}
\hline No. & Kriteria & Skor & f & $\%$ \\
\hline 1. & Sangat Baik & $>80$ & 32 & 10,22 \\
2. & Baik & $67-80$ & 89 & 28,43 \\
3. & Cukup & $54-66$ & 127 & 40,58 \\
4. & Tidak Baik & $41-53$ & 48 & 15,34 \\
5. & Sangat Tidak Baik & $\leq 40$ & 17 & 5,43 \\
\hline \multicolumn{2}{c}{ Total } & 313 & 100,00 \\
\hline
\end{tabular}

Sebagian besar responden mempunyai skor perilaku sopan santun kategori cukup, yaitu 127 responden $(40,58 \%)$. Hal ini didukung dengan nilai rata-rata sebesar 63,58, menunjukkan bahwa perilaku sopan santun peserta didik di SMP Negeri Sekecamatan Ngaglik Sleman Yogyakarta termasuk dalam kategori cukup.

Uji Persyaratan Analisis

Uji normalitas digunakan untuk mengetahui apakah model regresi berdistribusi normal atau tidak menggunakan Kolmogorov Smirnov yaitu membandingkan nilai probabilitas dengan nilai kritisnya yaitu 0,05 .

Tabel 4. Hasil Uji Kolmogorov Smirnov

\begin{tabular}{lccc}
\hline \multicolumn{1}{c}{ Variabel } & KS-Z & $\mathrm{p}$ & Ket. \\
\hline Pola asuh orang tua $\left(\mathrm{X}_{1}\right)$ & 0,550 & 0,923 & Normal \\
Ketaatan beribadah $(\mathrm{X} 2)$ & 1,086 & 0,189 & Normal \\
Perilaku sopan santun $(\mathrm{Y})$ & 1,211 & 0,106 & Normal \\
\hline
\end{tabular}

Berdasarkan hasil perhitungan diatas nilai $\mathrm{p}$ pada variabel pola asuh orang tua sebesar 0,669 atau lebih besar dari 0,05 maka data untuk variabel tersebut mempunyai sebaran yang merata (normal). Nilai p pada variabel ketaatan beribadah sebesar 0,189 atau lebih besar dari 0,05 maka data untuk variabel tersebut mempunyai sebaran yang merata (normal). Nilai p pada variabel perilaku sopan santun sebesar 0,106 atau lebih besar dari 0,05 maka data untuk variabel tersebut mempunyai sebaran yang merata (normal).

Pedoman yang digunakan untuk menguji linieritas garis regresi dilakukan dengan jalan menguji signifikansi nilai $\mathrm{F}$ pada baris deviation from linearity. Adapun hasil uji linieritas hubungan disajikan pada Tabel 5.

Tabel 5. Hasil Uji Linieritas

\begin{tabular}{cccc}
\hline Variabel & $\mathrm{F}$ & $\mathrm{p}$ & Ket \\
\hline Pola asuh orang tua $\left(\mathrm{X}_{1}\right)$ & 1,261 & 0,121 & Linear \\
Ketaatan beribadah $\left(\mathrm{X}_{2}\right)$ & 1,110 & 0,293 & Linear \\
\hline
\end{tabular}

Nilai $\mathrm{p}$ antara pola asuh orang tua $\left(\mathrm{X}_{1}\right)$ dan perilaku sopan santun $(\mathrm{Y})$ sebesar 0,121 atau lebih besar dari 0,05 maka hubungan antara kedua variabel tersebut linear. Nilai $\mathrm{p}$ antara ketaatan beribadah $\left(\mathrm{X}_{2}\right)$ dan perilaku sopan santun (Y) sebesar 0,293 atau lebih besar dari 0,05 maka hubungan antara kedua variabel tersebut linear.

Uji multikolinearitas untuk mengetahui adanya hubungan antara beberapa atau semua variabel yang menjelaskan dalam model regresi. Jika dalam model terdapat multikolinearitas maka model tersebut memiliki kesalahan standar yang besar sehingga koefisien tidak dapat ditaksir dengan ketepatan yang tinggi. Salah satu cara mendeteksi ada tidaknya multikolinearitas adalah dengan melihat nilai VIF. Hasil uji multikolinearitas disajikan pada Tabel 6.

Tabel 6. Hasil Uji Multikolinearitas

\begin{tabular}{cc}
\hline Variabel & VIF \\
\hline Pola asuh orang tua $\left(\mathrm{X}_{1}\right)$ & 1,059 \\
Ketaatan beribadah $\left(\mathrm{X}_{2}\right)$ & 1,059 \\
\hline
\end{tabular}

Berdasarkan hasil perhitungan di atas nilai VIF pada variabel pola asuh orang tua sebesar 1,059 atau lebih kecil dari 10 maka tidak ada gejala multikolinearitas. Nilai VIF pada variabel ketaatan beribadah sebesar 1,059 atau lebih kecil dari 10 maka tidak ada gejala multikolinearitas. Nilai tolerance yang mendekati angka 1 juga menunjukkan tidak adanya multikolinieritas. 


\section{Uji Hipotesis}

Pengujian hipotesis dilaksanakan untuk membuktikan apakah hipotesis yang diajukan yang sifatnya sementara benar-benar terbukti atau tidak. Persyaratan uji normalitas, linearitas dan multikolinearitas sudah terpenuhi dan untuk mengetahui hubungan antara variabel bebas dengan variabel terikat maka dilakukan uji hipotesis. Penelitian ini menggunakan teknik analisis korelasi product moment dan regresi ganda dengan dua prediktor untuk mengetahui hubungan variabel bebas secara yaitu pola asuh orang tua $\left(\mathrm{X}_{1}\right)$ dan ketaatan beribadah (X2) secara bersama-sama dengan variabel terikat perilaku sopan santun (Y).

Hasil pengujian korelasi product moment dirangkumkan dalam Tabel 7.

Tabel 7. Hasil Pengujian Korelasi Product Moment

\begin{tabular}{|c|c|c|c|c|}
\hline & & $\begin{array}{l}\text { Pola asuh } \\
\text { orang tua }\end{array}$ & $\begin{array}{c}\text { Ketaatan } \\
\text { beribadah }\end{array}$ & $\begin{array}{c}\text { Perilaku } \\
\text { sopan } \\
\text { santun }\end{array}$ \\
\hline \multirow{2}{*}{$\begin{array}{l}\text { Pola asuh } \\
\text { orang tua }\end{array}$} & $\mathrm{r}$ & 1 & & 0,480 \\
\hline & $\mathrm{p}$ & . & & 0,000 \\
\hline \multirow{2}{*}{$\begin{array}{l}\text { Ketaatan } \\
\text { beribadah }\end{array}$} & $\mathrm{r}$ & & 1 & 0,453 \\
\hline & $\mathrm{p}$ & & & 0,000 \\
\hline \multirow{2}{*}{$\begin{array}{l}\text { Perilaku sopan } \\
\text { santun }\end{array}$} & $\mathrm{r}$ & 0,480 & 0,453 & 1 \\
\hline & $\mathrm{p}$ & 0,000 & 0,000 & \\
\hline
\end{tabular}

Hasil pengujian regresi ganda dengan dua prediktor dirangkumkan dalam Tabel 8 .

Tabel 8. Tabel 8. Hasil Pengujian Regresi Ganda dengan Dua Prediktor

\begin{tabular}{lccccc}
\hline \multicolumn{1}{c}{ Model } & $\begin{array}{l}\text { Kof. } \\
\text { Reg. }\end{array}$ & SE & $\beta$ & $\mathrm{t}$ & $\mathrm{p}$ \\
\hline $\begin{array}{l}\text { Konstan } \\
\text { Pola asuh } \\
\text { orang tua }\end{array}$ & 17,414 & 3,599 & & 4,838 & 0,000 \\
$\begin{array}{l}\text { Ketaatan } \\
\text { beribadah }\end{array}$ & 0,405 & 0,050 & 0,396 & 8,416 & 0,000 \\
$\mathrm{R}=0,594$ & & & & & \\
$\mathrm{R}^{2}=0,353$ & & & & & \\
$\mathrm{~F}=84,547$ & & & & & 0,000 \\
\hline
\end{tabular}

\section{Pengujian Hipotesis Pertama}

Hipotesis alternatif pertama $\left(\mathrm{H}_{\mathrm{a} 1}\right)$ dalam penelitian ini berbunyi "Ada hubungan yang positif dan signifikan pola asuh orang tua dengan perilaku sopan santun peserta didik di seluruh SMP Negeri Kecamatan Ngaglik Kabupaten Sleman". Pada pengujian secara statistik hipotesis alternatif dirubah menjadi hipotesis statistik atau hipotesis nihil $\left(\mathrm{H}_{01}\right)$ dan berbunyi "Tidak ada hubungan yang positif dan signifikan pola asuh anak dengan perilaku sopan santun peserta didik di seluruh SMP Negeri Kecamatan Ngaglik Kabupaten Sleman"

Berdasarkan hasil pengujian korelasi product moment pola asuh orang tua dengan perilaku sopan santun didapatkan nilai $r$ hitung sebesar 0,480 dengan $\mathrm{p}$ sebesar 0,000. Berdasarkan nilai $\mathrm{p}<0,05$, maka $\mathrm{H}_{0}$ ditolak sehingga disimpulkan ada hubungan yang positif antara pola asuh orang tua dengan perilaku sopan santun. Semakin baik pola asuh orang tua maka semakin baik pula perilaku sopan santun siswa.

\section{Pengujian Hipotesis Kedua}

Hipotesis alternatif kedua $\left(\mathrm{H}_{\mathrm{a} 2}\right)$ dalam penelitian ini berbunyi "Ada hubungan yang positif dan signifikan ketaatan beribadah dengan perilaku sopan santun peserta didik di seluruh SMP Negeri Kecamatan Ngaglik Kabupaten Sleman". Pada pengujian secara statistik hipotesis alternatif dirubah menjadi hipotesis statistik atau hipotesis nihil $\left(\mathrm{H}_{02}\right)$ dan berbunyi " Tidak ada hubungan yang positif dan signifikan ketaatan beribadah dengan perilaku sopan santun peserta didik di seluruh SMP Negeri Kecamatan Ngaglik Kabupaten Sleman"

Berdasarkan hasil pengujian korelasi product moment ketaatan beribadah dengan perilaku sopan santun didapatkan nilai r-hitung sebesar 0,453 dengan $\mathrm{p}$ sebesar 0,000. Berdasarkan nilai $\mathrm{p}<0,05$, maka Ho ditolak sehingga disimpulkan ada hubungan yang positif antara ketaatan beribadah dengan perilaku sopan santun. Semakin baik ketaatan beribadah maka semakin baik pula perilaku sopan santun siswa.

\section{Pengujian Hipotesis Ketiga}

Hipotesis alternatif ketiga $\left(\mathrm{H}_{\mathrm{a} 3}\right)$ dalam penelitian ini berbunyi "Ada hubungan yang positif dan signifikan pola asuh orang tua dan ketaatan beribadah secara bersama-sama dengan perilaku sopan santun peserta didik di 
seluruh SMP Negeri Kecamatan Ngaglik Kabupaten Sleman". Pada pengujian secara statistik hipotesis alternatif dirubah menjadi hipotesis statistik atau hipotesis nihil $\left(\mathrm{H}_{03}\right)$ dan berbunyi" Tidak ada hubungan yang positif dan signifikan pola asuh anak dan ketaatan beribadah secara bersama-sama dengan perilaku sopan santun peserta didik di seluruh SMP Negeri Kecamatan Ngaglik Kabupaten Sleman".

Berdasarkan hasil pengujian regresi ganda dengan dua prediktor didapatkan nilai F-hitung sebesar 84,547 dengan $\mathrm{p}$ sebesar 0,000 . Berdasarkan nilai $\mathrm{p}<0,05$, maka Ho ditolak sehingga disimpulkan ada hubungan yang positif antara pola asuh orang tua dan ketaatan beribadah dengan perilaku sopan santun. Semakin baik pola asuh orang tua dan semakin taat beribadah siswa maka semakin baik perilaku sopan santunnya.

Besarnya pengaruh pola asuh orang tua dan ketaatan beribadah terhadap perilaku sopan santun, ditunjukkan dari nilai koefisien determinasi $\left(\mathrm{R}^{2}\right)$. Nilai $\mathrm{R}^{2}$ didapatkan sebesar 0,353 , sehingga pengaruh pola asuh orang tua dan ketaatan beribadah terhadap perilaku sopan santun sebesar 35,3\% sedangkan sisanya $64,7 \%$ dipengaruhi oleh variabel diluar penelitian.

Pembahasan

Pola Asuh Orang Tua Dengan Perilaku Sopan Santun

Hasil penelitian didapatkan pola asuh orang tua mempunyai hubungan positif dengan perilaku sopan santun. Semakin baik pola asuh orang tua semakin baik pula perilaku sopan santun siswa, begitu juga sebaliknya semakin kurang pola asuh orang tua semakin berkurang pula perilaku sopan santun siswa.

Orang tua akan menerapkan pola asuh tertentu sesuai dengan situasi dan kondisi masing-masing anak. Orang tua berupaya menanamkan kesopanan anak dengan meletakkan nilai-nilai dan norma ke dalam diri anak sehingga anak memiliki kesopanan. Orang tua memberikan contoh dan keteladanan dengan berperilaku sesuai dengan nilai-nilai moral dan merealisasikan nilai-nilai moral dalam kehidupan sehari-hari.

Moral merupakan acuan universal dalam bertingkah laku. Istilah "moral" mempunyai dua arti, yang pertama bertalian de- ngan kemampuan seseorang untuk memahami moralitas maupun kemampuan untuk membuat keputusan moral, sedangkan yang kedua bertalian dengan penampilan yang senyatanya dari tindakan moral. Santrock (2010, p.373) menjelasakan sebagai berikut.

Moral competencies include what individuals are capable of doing, what they know, their skills, their awareness of moral rules and regulations, and their cognitive ability to construct behaviors.

Kompetensi moral termasuk apa yang orang mampu lakukan dan ketahui, keterampilan, kesadaran terhadap aturan untuk membangun perilaku. Menurut Lerner, et al (2003, p.247), “...in which children's moral values develop out of a unilateral respect for authority, to an autonomous stage, in which conceptions of reciprocity and equality emerge". Pada masa anak-anak moral juga berkembang dari rasa hormat menjadi semua orang adalah sama.

Nilai-nilai moral dalam masyarakat bersumber pada nilai agama yang diyakini oleh suatu kelompok. Moral di dalam agama lebih dikenal dengan istilah akhlak. Batasan akhlak di dalam agama Islam, baik akhlak terhadap Sang Pencipta, sesama manusia maupun terhadap alam telah ditentukan oleh Alquran dan hadis sehingga manusia dapat menjadikan kedua sumber tersebut sebagai pedoman dalam berakhlak. Sumber untuk menentukan akhlak dalam Islam, apakah termasuk akhlak yang baik atau akhlak yang tercela, sebagaimana keseluruhan ajaran Islam lainnya adalah Alquran dan Sunnah Nabi Muhammad (Marzuki, 2009, p.19).

Alquran sebagai sumber akhlak dalam Islam. Berikut ini salah satu ayat mengenai akhlak:

Sesungguhnya telah ada pada (diri) Rasulullah itu suri teladan yang baik bagimu (yaitu) bagi orang yang mengharap (rahmat) Allah dan (kedatangan) hari kiamat dan dia banyak menyebut Allah". (Q.S. Al- Ahzab 33:21).

Hadits sebagai sumber akhlak dalam Islam. Berikut ini salah satu hadits yang berkenaan dengan akhlak: "innama bu'itstu liutammimamakaarimal akhlaaq" Sesungguhnya 
aku diutus hanyalah untuk menyempurnakan akhlak manusia (HR Malik) (Sodikin, 2009, p.12). Alquran dan Hadits merupakan sumber akhlak dalam Islam.

Nilai-nilai moral yang bersumber dari agama memberikan pengertian yang lebih jelas mengenai perilaku yang seharusnya dilakukan dan tidak dilakukan. Nilai ini bersifat universal sehingga dapat diterima oleh kelompok sosial di manapun kelompok itu berada (Ibda, 2012, p.342).

Perilaku sopan santun juga berkaitan dengan etika. Bertens (2007, p.6) menyebutkan bahwa etika mempunyai tiga arti: Pertama, etika dalam arti nilai-nilai atau normanorma yang menjadi pegangan bagi seseorang atau kelompok dalam mengatur tingkah lakunya. Pengertian ini bisa dirumuskan juga sebagai suatu nilai yang dapat berfungsi dalam hidup manusia, perorangan maupun pada tataran sosial. Kedua, etika dalam arti kumpulan asas atau nilai moral. Dalam hal ini etika dimaksudkan sebagi kode etik. Ketiga, etika dalam arti ilmu tentang yang baik atau buruk.

Sopan santun membutuhkan penanaman perilaku melalui pembiasaan (Haerudin, 2013, p.171). Kebiasaan dapat dilatih sejak dini meliputi menerima dan memberi dengan tangan kanan, mengucapkan terima kasih, cara berpakaian, dan cara bersikap terhadap orang lain. Dalam hal ini, orang tua memegang peran sangat menentukan karena anak lebih banyak bersama orang tua. Hasil penelitian ini memperkuat penjelasan Hope, et. al (2003) bahwa moralitas orang tua atau orang dewasa dalam keluarga akan berpengaruh tehadap moraitas anaknya. Penelitian Buehler (2006) menyatakan kontrol orang tua baik bapak maupun ibu dapat mengurangi perilaku bermasalah pada anak-anak yang memasuki masa remaja.

\section{Ketaatan Beribadah dengan Perilaku Sopan Santun}

Hasil penelitian didapatkan ketaatan beribadah mempunyai hubungan positif dengan perilaku sopan santun. Semakin tinggi ketaatan beribadah siswa semakin baik pula perilaku sopan santun siswa, begitu juga sebaliknya semakin rendah ketaatan beribadah siswa semakin berkurang pula perilaku sopan santun siswa.
Ketaatan beribadah anak akan terlihat dari perilakunya dalam sehari-hari baik di lingkungan masyarakat ataupun lingkungan sekolah. Ketaatan beribadah bukanlah sebagai rangkaian ritual semata akan tetapi mengandung nilai-nilai luhur yang dapat membawa manusia pada ketenangan dan kebahagiaan jiwa.

\section{Pengaruh Pola Asuh Orang Tua dan Ketaatan Beribadah terhadap Perilaku Sopan Santun}

Ketaatan beribadah juga memotivasi seseorang untuk melakukan suatu aktivitas yang berdasarkan nilai-nilai agama. Motivasi mendorong seseorang untuk berbuat kebajikan maupun berkorban seperti tolong menolong dan sebagainya. Ketaatan beribadah yang dilakukan oleh seorang anak dapat memberikan motivasi dalam melakukan suatu perbuatan yang baik. Nilai-nilai keagamaan berhubungan positif dengan kesopanan anak. Hal ini memperkuat pendapat Christianingrum (2013) bahwa keluarga dan ketaatan beribadah terhadap sikap remaja dalam menghindari seks bebas.

Hasil penelitian didapatkan pola asuh orang tua dan ketaatan beribadah mempunyai hubungan positif dengan perilaku sopan santun. Semakin baik pola asuh orang tua dan semakin taat beribadah siswa maka semakin baik perilaku sopan santun dan santun, demikian pula sebaliknya semakin berkurang pola asuh orang tua dan ketaatan beribadah siswa, maka perilaku sopan santun akan berkurang.

Pembentukan sopan santun dimulai dari keluarga yang memberikan contoh baik secara langsung maupun tidak langsung. Anak akan meniru perilaku orang tua dalam kehidupan sehar-hari. Anak yang mempunyai perilaku sopan dapat dipastikan keluarganya juga sopan, demikian pula sebaliknya anak yang mempunyai perilaku kasar tentunya perilaku keluarga juga kasar. Skinner (Putra, 2013, p.44) merumuskan bahwa perilaku merupakan respon atau reaksi seseorang terhadap stimulasi merupakan respons atau reaksi seseorang terhadap stimulus (rangsangan dari luar). Oleh karena perilaku ini terjadi melalui proses adanya stimulasi terhadap organisme, dan kemudian organisme tersebut merespons, maka teori Skiner ini disebut teori "S-O-R atau Stimulus Organisme Respons". Skiner 
membedakan adanya dua respons (Notoatmodjo, 2010, p.20).

Respondent respons atau reflexive, yakni respons yang ditimbulkan oleh rangsangan-rangsangan (stimulus) tertentu. Stimulus semacam ini disebut eleciting stimulation karena menimbulkan respons-respons yang relatif tetap. Misalnya: Makanan yang lezat menimbulkan keinginan untuk makan, cahaya terang menyebabkan mata tertutup, dan sebagainya. Respondent respons ini juga mencakup perilaku emosional, misalnya mendengar berita musibah menjadi sedih atau menangis, lulus ujian meluapkan kegembiraanya dengan mengadakan pesta, dan sebagainya.

Operant respons atau instrumental respons, yakni respons yang timbul dan berkembang kemudian diikuti oleh stimulus atau perangsang tertentu. Perangsang ini disebut reinforcing stimulation atau reinforce, karena memperkuat respons. Misalnya apabila seorang petugas kesehatan melaksanakan tugasnya dengan baik kemudian memperoleh penghargaan dari atasannya (stimulus baru), maka petugas kesehatan tersebut akan lebih baik lagi dalam melaksanakan tugasnya.

Perilaku manusia terbentuk di dalam diri seseorang dari dua faktor utama yakni stimulus merupakan faktor dari luar diri seseorang tersebut (faktor eksternal) dan respons merupakan faktor dari diri dalam diri orang yang bersangkutan (faktor internal). Faktor eksternal atau stimulus adalah merupakan faktor lingkungan, baik lingkungan fisik, dan nonfisik dalam bentuk sosial, budaya, ekonomi, politik, dan sebagainya.

Penelitian-penelitian yang ada faktor eksternal yang paling besar pengaruhnya dalam membentuk perilaku manusia adalah faktor sosial dan budaya di mana seseorang tersebut berada. Sedangkan faktor internal yang menentukan seseorang itu merespons stimulus dari luar adalah perhatian, pengamatan, persepsi, motivasi, fantasi, sugesti, dan sebagainya (Notoatmodjo, 2010, p.22).

Di samping pola asuh orang tua, ketaatan beribadah akan membentuk siswa menjadi taat akan perintah agama termasuk menghormati orang tua, saling kasih sayang dan sebagainya, semuanya itu akan membentuk perilaku yang baik.

Ketaatan beribadah kepada Allah memberi pengaruh yang baik dalam diri anak, karena anak memiliki ikatan yang kuat dengan
Allah, perasaan emosional terkendali, dan hawa nafsu terpelihara sehingga anak berperilaku lurus dan bersikap istiqamah. Ibadah merupakan upaya mewujudkan ketenangan, kedamaian, kebahagiaan dan kesehatan mental (Rajab, 2011, p.75).

Ketaatan beribadah akan membentuk perilaku pada anak seperti sopan santun, tolong menolong, saling sayang menyayangi dan sebagainya. Perintah agama pada dasarnya sejalan dengan nilai-nilai moral ataupun sopan santun.

Hal ini memperkuat pernyataan dari penelitian King and Furrow (2004) yang menyebutkan bahwa ketaatan beragama akan mempertinggi perilaku moral remaja. Horwart et al (2012) menyatakan bahwa baik orangorang muda dan orang tua, agama memiliki pengaruh yang signifikan dan positif terhadap kehidupan mereka. Keyakinan beragama dan praktik dalam menjalankan agama akan mempengaruhi perilaku dan gaya hidup.

\section{Simpulan dan Saran}

Simpulan

Ada hubungan yang positif dan signifikan antara pola asuh anak dengan perilaku sopan santun peserta didik di seluruh SMP Negeri Kecamatan Ngaglik Kabupaten Sleman. Semakin baik pola asuh orang tua semakin baik pula perilaku sopan santun siswa, begitu juga sebaliknya semakin buruk pola asuh orang tua semakinburuk pula perilaku sopan santunnya.

Ada hubungan yang positif dan signifikan antara ketaatan beribadah dengan perilaku sopan santun peserta didik di seluruh SMP Negeri Kecamatan Ngaglik Kabupaten Sleman. Semakin baik ketaatan siswa dalam beribadah maka semakin baik sopan santun siswa, begitu pula sebaliknya semakin siswa kurang taat beribadah maka semakin buruk sopan santunnya.

Ada hubungan yang positif dan signifikan antara pola asuh orang tua dan ketaatan beribadah secara bersama-sama dengan perilaku sopan santun peserta didik di seluruh SMP Negeri Kecamatan Ngaglik Kabupaten Sleman. Semakin baik pola asuh orang tua dan ketaatan beribadah siswa maka semakin baik sopan santun peserta didik, begitu pula sebaliknya semakin buruk pola asuh orang tua dan 
ketaatan beribadah siswa maka semakin buruk sopan santunnya.

Saran

Guru dan Kepala Sekolah SMP Negeri di Kecamatan Ngaglik Sleman, sebaiknya menyelenggarakan kegiatan-kegiatan yang berhubungan dengan peningkatan pola asuh orang tua. Orang tua sebaiknya menerapkan pola asuh yang baik agar perilaku anak lebih menunjukkan perilaku sopan santun. Penelitian lebih lanjut disarankan agar penelitian ini dikembangkan dengan cakupan wilayah yang lebih luas.

\section{Daftar Pustaka}

Azwar, S. (2012). Penyusunan skala psikologi. Yogyakarta: Pustaka Pelajar.

Buehler, C (2006). Parents and peers in relation to early adolescent problem behavior. Journal of Marriage and Family, Vol. 68: 109-124

Christianingrum, R. (2013, November). Keluarga dan ketaatan beribadah terhadap sikap remaja dalam menghindari seks bebas dengan analisis jalur pada data kategori. Makalah disajikan dalam seminar Nasional Matematika dan Pendidikan Matematika, Univer-sitas Negeri Yogyakarta.

Hairuddin. (2013). Pendidikan karakter berbasis sunnah nabi, Jurnal Al-Ulum (Jurnal Studi-Studi Islam) IAIN Gorontalo, Volume. 13 Nomor 1, Juni 2013, hlm. 167-190

Hope, TL et al. (2003). The Relationship among adolescent pregnancy, pregnancy resolution and juvenile. The Sociological Quartely Vol 44. No 4.

Horwart J, Lees J and Sidebotham P (2012) The influence of religion on adolescent family life in england: an explanatory study of the views of young people and parents. Social Compas, Vol. 59 (2).

Johnson, B \& Christensen, L. (2012). Educational research quantitative, qualitative, and mixed approaches. Osaka: Sage Publication, Inc.
King PE and Furrow JL (2004) Religion as a resource for positive youth development: religion, social capital, and moral outcomes. Developmental Psychlogy, Vol. 40 (5).

La Raman, Zamroni, Pendidikan Karakter Siswa I SMP Muhammadiyah 1 Yogyakarta dan SMP Muhammadiyah 1 Kota Tidore, Harmoni Sosial, Volume 1 Nomor 1, 2014, 12-26

Marzuki, (2009), Prinsip dasar akhlak mulia pengantar studi konsep-konsep dasar etika dalam Islam, Yogyakarta, Debut Wahana Press

Mu'niah (2011), Materi pendidikan agama islam untuk perguruan tinggi, Yogyakarta, Ar-Ruzz Media.

Notosoedirdjo, M. \& Latipun, (2011) Kesehatan Mental, Malang, UPT Universitas Muhammadiyah Malang Press.

Rajab, K (2011). Psikologi ibadah: memakmurkan kerajaan ilahi di hati manusia, Jakarta: Amzah.

Rosadi, I. (2010). Perbandingan perilaku agama anak dengan pola asuh keluarga yang bervariasi di desa depok kecamatan depok kabupaten cirebon. Tesis dipublikasikan, Program Pascasarjana IAIN Syekh Nuryati Cirebon.

Shaffer, DR \& Kipp K (2014). Developmental psychology: childhood an adolescence, 9th Edition. Canada: Wadswort Cengage Learning.

Ujiningsih \& Antoro, S.D. (2010). Pembudayaan sikap sopan santun di rumah dan di sekolah sebagai upaya untuk meningkatkan karakter siswa, Makalah disampaikan dalam Temu Ilmiah Nasional Guru II 2010 Universitas Terbuka.

Widarjono, A. (2007). Ekonometrika: teori dan aplikasi untuk ekonomi dan bisnis. Yogyakarta: Ekonisia FE UII Yogyakarta.

Yusuf, S. (2008). Psikologi perkembangan anak \& remaja. Bandung: PT. Remaja Rosdakarya.

Zuriah, N, (2008), Pendidikan moral \& budi pekerti dalam perspektif perubahan, Jakarta, PT Bumi Aksara. 